Marquette University Law School

Marquette Law Scholarly Commons

Faculty Publications

Faculty Scholarship

$1-1-2008$

\title{
A Historical Review of Title IX Litigation
}

Paul M. Anderson

Marquette University Law School, paul.anderson@marquette.edu

Barbara Osborne

University of North Carolina at Chapel Hill

Follow this and additional works at: http://scholarship.law.marquette.edu/facpub

Part of the Law Commons

Publication Information

Paul Anderson \& Barbara Osborne, A Historical Review of Title IX Litigation, 18 J. Legal Aspects Sport 127 (2008). Copyright (C) 2008 by the Sport and Recreation Law Association.

\section{Repository Citation}

Anderson, Paul M. and Osborne, Barbara, "A Historical Review of Title IX Litigation" (2008). Faculty Publications. Paper 582.

http://scholarship.law.marquette.edu/facpub/582

This Article is brought to you for free and open access by the Faculty Scholarship at Marquette Law Scholarly Commons. It has been accepted for inclusion in Faculty Publications by an authorized administrator of Marquette Law Scholarly Commons. For more information, please contact megan.obrien@marquette.edu. 


\title{
REPORT
}

\section{A Historical Review of Title IX Litigation ${ }^{1}$}

\author{
PAUL ANDERSON \\ National Sports Law Institute of Marquette University Law School \\ \& \\ BARBARA OSBORNE \\ University of North Carolina at Chapel Hill
}

\section{INTRODUCTION}

2007 marked the 35th anniversary of the enactment of Title IX. ${ }^{2}$ Since its enactment, perhaps no other federal statute has had a greater impact on the operation of athletics, especially at the collegiate and high school levels.

Although the law's impact has been felt in the athletic realm, Title IX is not focused on athletics. Instead, Title IX focuses on educational activities provided by schools and other institutions as it states that "[n]o person in the United States shall, on the basis of sex, be excluded from participation in, be denied the benefits of, or be subjected to discrimination under any education program or activity receiving Federal financial assistance." ${ }^{3}$

The law's application to athletics has come through various regulations, interpretations, and clarifications as well as numerous lawsuits brought by individuals and groups who have felt excluded, denied or discriminated against within these educational programs and activities. These regulations, interpretations, clarifications and lawsuits have then determined the extent of the application of Title IX to athletics and contributed to the understanding and development of this important law.

1. This article is based on information originally presented in an earlier form at the Sport \& Recreation Law Association's Annual Conference on February 28, 2007.

2. Title IX of the Education Amendments of 1972, 20 U.S.C. §1681, et. seq. (2007).

3. Id. $§ 1681(\mathrm{a})$. 
The purpose of this research is to analyze the history of the litigation and other important developments that have taken place since the enactment of Title IX in 1972. By understanding this history, and the significant developments that have taken place along the way, practitioners, scholars and athletic participants can better understand the various ways that Title IX impacts athletics.

\section{METHODOLOGY}

Research for this study was conducted on the Westlaw and Lexis/Nexis legal research databases in order to ensure that the results found were the most complete possible. $^{4}$ In addition, because Westlaw and Lexis/Nexis do not carry the same cases, it was important to conduct research on both systems in order to ensure that the results were as complete as possible. Research was conducted in four distinct steps.

\section{Step One}

The first step involved general research for cases involving Title IX on comprehensive case search databases. On Westlaw, this initial search was conducted in the "All State and Federal Cases" database "ALLCASES." On Lexis/Nexis, this initial search was conducted in the "Federal and State Cases, Combined" database. Both of these databases provide comprehensive access to all of the cases contained on each search engine.

Each initial search was done using terms and connectors searching with the specific terms - "Title IX" or "Education Amendments" or "20 U.S.C. $\S 1681 . "$ The "or" connector was specifically selected so that cases would be found containing any of the terms individually or containing any combinations of the terms.

Each search was done for each individual year by specifying inclusive yearlong date ranges (e.g. from 1//1/1972 to 12/31/1972) to ensure that no cases were missed.

Finally, the case results were separated by year and put into initial tables. Overall, at this step there were over 1000 cases initially collected.

4. Westlaw, www.westlaw.com (last visited Jan. 1, 2008); LexisNexis Total Research System, www.lexis.com (last visited Jan. 1, 2008). 


\section{Step Two}

After completing the initial case searches by year, the second step focused on Shephardizing Title IX and the law's implementing regulations. ${ }^{5}$ When one enters a case citation into Shephards on Lexis the results will show the prior history to that case along with any further case history that may have impacted that case. In addition, for cases or any other sources that Shephards indexes, it will provide references to any other sources that refer to the initial source. Therefore, by inserting the citation to Title IX (20 U.S.C. \$1681(a)) and the regulations (34 C.F.R. 106.41) one can cross reference any cases or other sources that have mentioned either the law or the regulations. As of January 3, 2008, the Shepards report for Title IX (20 U.S.C. §1681(a)) included 653 references to cases.

The Shepards results for the law and regulations were then cross referenced with the results found in Step One. Any new cases were then added into the overall case results tables.

\section{Step Three}

After collecting all of the cases from Steps One and Two, the authors began to review the cases to determine whether they were in some way connected to athletics. Of particular note, only cases that specifically involved situations within the sport or athletic context were included. Many cases dealing with Title IX in the educational setting (the actual focus of the law) were not included. These cases focused on many different claims including discrimination in hiring or promotions of teachers; sexual harassment of teachers or students; retaliation in hiring or firing of teachers; claims of discrimination in sports in prisons; and student claims related to admissions, awards or course work. As a result, several of the cases that developed the claims that can be brought under Title IX are not included in the research results, although they will be mentioned in this article, because they are not sport cases. ${ }^{6}$

As the final part of this step, a final follow-up search was conducted on Lexis searching for - "Title IX" or "Education Amendments" or "20 U.S.C. §1681" and sport or athlet!, focusing on cases from 1972 to the end of 2007. The "!" connector was used in order to ensure that the search found cases with

5. Shepards is a citation service owned by LexisNexis that is typically used to validate case results.

6. See, e.g., Grove City Coll. v. Bell, 465 U.S. 555 (1984). 
words including "athlete," "athletic," and other similar words. This final search focused only on cases in sport or athletics to insure that no cases were missed.

\section{Step Four}

In the Step Four, cases were reviewed with a focus on results that actually dealt with Title IX. Cases were included in the results portion of this study only if they dealt with dispositive claims and outcomes that dealt with a Title IX issue. For ease of understanding, claims were separated into the following eleven general categories:

- Exclusion of boys from girls teams

- Exclusion of girls from boys teams

- $\quad$ Program inequalities (equal opportunity) ${ }^{7}$

- Accommodation issues (interests and abilities) ${ }^{8}$

- Sexual harassment claims against a coach or school

- Peer sexual harassment claims

- Elimination of boys teams or opportunities

- Elimination of girls teams

- Employment discrimination

- Other (a catchall for remaining claims)

At the same time, to categorize the results in these cases, the case outcomes were separated into seven distinct categories:

- Motion - claims dismissed (no Title IX decision)

- Motion - claims proceed / remand

- Motion for summary judgment granted / Claim dismissed (claim ends with no Title IX violation found)

- Motion for summary judgment granted / Claim dismissed (claim ends with Title IX violation found)

- No Title IX violation

- Title IX violation

7. These claims focus on different aspects of an athletic program, including equipment, facilities, monetary support, and scheduling of sports.

8. These claims focus on the accommodation of the interests and abilities of athletes as described in the three part test that will be discussed infra. 
- Other

Finally, important developments impacting Title IX, including government interpretations and clarifications, and cases not impacting athletics (although not included in the overall numbers), are included in the study.

\section{RESULTS}

The results of this study were separated into two distinct categories, (1) overall results, and (2) results categorized by decade. Of specific note, for each decade the authors also focused on important developments and case decisions during that time period, in addition to an overall analysis of the claims brought and outcomes realized during that time.

\section{Overall}

Overall this study found 190 cases involving Title IX claims in the athletic setting. ${ }^{9}$ Over the 36 year span covered, there was an average 5.3 cases per year. Interestingly, in seven years during this time period (1972, 1973, 1974, 1975, 1984, 1989 and 1990), there were no Title IX cases found.

The first Title IX case was in $1976 .^{10}$ Still, it is important to note that almost half of the cases (47\%) found were decided in the past eight years, with 89 cases from 2000-2007. Adding the 69 cases found in the 1990 s (or 36\% of the total) to these 89 cases, $83 \%$ of the cases found in this study were decided since 1990 , while only $17 \%$ of the cases found were in the 1970 s or 1980 s $(1970 \mathrm{~s}=7$ cases $=4 \% \mid 1980 \mathrm{~s}=25$ cases $=13 \%)$.

Figure 1 illustrates the increasing number of Title IX cases over the past 36 years.

9. As a final clarification, it should be understood that many Title IX cases have an extensive procedural history. The authors determined to include only cases that involved actual substantive decisions related to the Title IX claims and outcomes mentioned in Step Four. Therefore, decisions involving petitions to intervene or extension orders, were not included in these results.

For example, the Communities for Equity case, initially 26 F. Supp. 2d 1001 (W.D. Mich. 1998), involves 28 separate court decisions found on the Lexis search engine; however, only seven of those decisions dealt with substantive issues categorized in this research study.

10. Cape v. Tennessee Secondary Sch. Athletic Ass'n., 424 F. Supp. 732 (E.D. Tenn. 1976). 
FIGURE 1

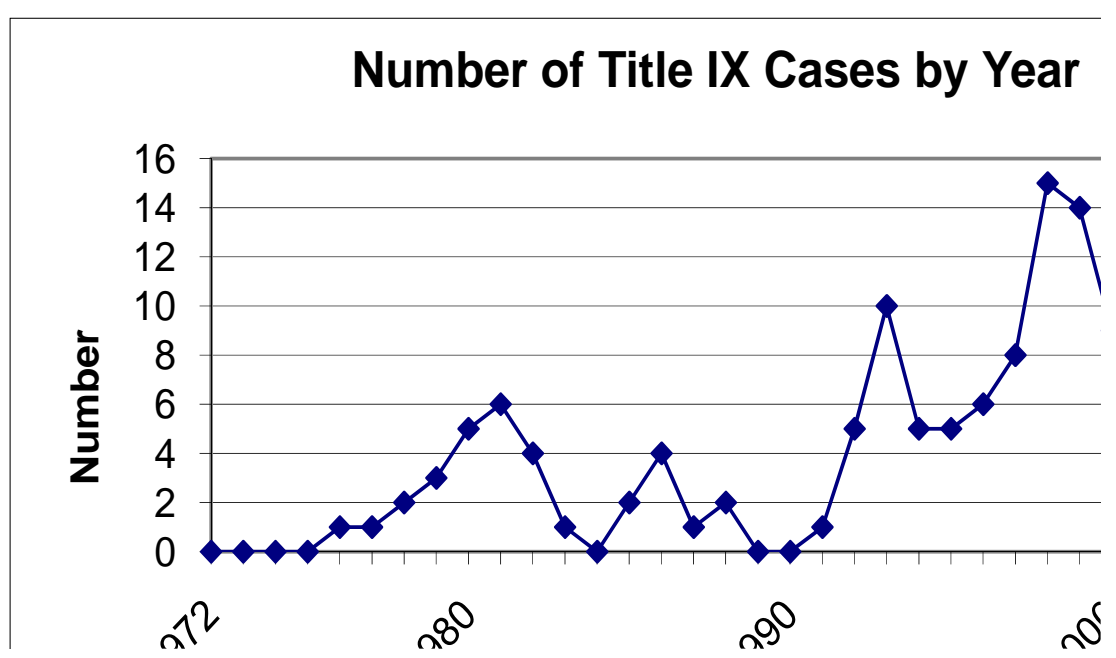

The highest number of cases were found in 1998 with 15 decisions. Four other years had 14 decisions including 1999, 2002, 2006, and 2007.11

The 190 cases found in this study were decided in 35 different states and the District of Columbia. This means that $70 \%$ of the states in the United States have encountered some form of Title IX litigation in the athletics area. The average amount of cases per state was 5.3, with a median of 3 cases.

The state with the highest number of Title IX related cases was Pennsylvania with 19, followed by New York with 15, Illinois with 13, North Carolina with 11, and five states with 10 cases each. These nine states (Pennsylvania, New York, Illinois, North Carolina, Alabama, Kansas, Ohio, Michigan, and Texas) accounted for $57 \%$ of the total cases found. Fifteen states represent the low end of the range with no Title IX sports cases that have been reported. Interestingly, 11 of these 15 states are currently among the lowest in population density. ${ }^{12}$ Table 1 lists the Title IX sports decisions by state.

11. Some of the cases found in these years are different decisions within the same litigation.

12. Data extracted from: U.S. Census Bureau, Cumulative Estimates of Population change for the United States, States, \& Puerto Rico - April 1, 2000 - July 1, 2007, available at http://www.census.gov/popest/gallery/maps/maps-state2007.xls (last visited Jan. 24, 2008). 
TABLE 1: CASES BY STATE

STATE

Alabama

Arkansas

California

Colorado

Connecticut

Delaware

Florida

Georgia

Illinois

Indiana

Iowa

Kansas

Kentucky

Louisiana

Massachusetts

Michigan

Minnesota

Missouri

Montana

Nebraska

New Jersey

New Hampshire

New York

North Carolina

North Dakota

Ohio

Oklahoma

Pennsylvania

Rhode Island

Tennessee

Texas

Utah

Virginia

Wisconsin

Washington

District of Columbia

TOTAL

NUMBER OF CASES

10

1

8

5

3

1

5

3

13

1

3

10

2

3

2

10

6

1

3

4

1

1

15

11

2

10

2

19

8

2

10

1

5

3

1

5

190 
Title IX cases have been litigated in both state and federal courts. In the state courts, seven cases have been decided at the state appellate court level. Only one case has been decided by a state Supreme Court, Alabama's in 1998. ${ }^{13}$ As Title IX is federal legislation, most cases have been litigated in federal courts. There have been 130 decisions rendered by federal district courts and 47 in the U.S. Court of Appeals. Five sports-related Title IX cases have been decided by the U.S. Supreme Court. ${ }^{14}$

TABLE 2: CASES BY COURT

\begin{tabular}{|c|c|c|c|c|c|}
\hline & $\begin{array}{c}\text { State Court } \\
\text { of Appeal }\end{array}$ & $\begin{array}{c}\text { State } \\
\text { Supreme } \\
\text { Court } \\
\end{array}$ & $\begin{array}{l}\text { U.S. District } \\
\text { Court }\end{array}$ & $\begin{array}{l}\text { U.S. Court } \\
\text { of Appeal }\end{array}$ & $\begin{array}{c}\text { Supreme } \\
\text { Court }\end{array}$ \\
\hline \multicolumn{6}{|l|}{1972} \\
\hline \multicolumn{6}{|l|}{1973} \\
\hline \multicolumn{6}{|l|}{1974} \\
\hline \multicolumn{6}{|l|}{1975} \\
\hline 1976 & & & 1 & & \\
\hline 1977 & & & 1 & & \\
\hline 1978 & & & 2 & & \\
\hline 1979 & & & 2 & 1 & \\
\hline 1980 & 2 & & 1 & 1 & 1 \\
\hline 1981 & & & 4 & 2 & \\
\hline 1982 & & & 2 & 1 & 1 \\
\hline 1983 & & & 1 & & \\
\hline \multicolumn{6}{|l|}{1984} \\
\hline 1985 & & & 2 & & \\
\hline 1986 & & & 2 & 2 & \\
\hline 1987 & & & 1 & & \\
\hline 1988 & & & 1 & 1 & \\
\hline \multicolumn{6}{|l|}{1989} \\
\hline \multicolumn{6}{|l|}{1990} \\
\hline 1991 & & & 1 & & \\
\hline 1992 & & & 4 & & 1 \\
\hline
\end{tabular}

13. H.M. v. Jefferson County Bd. of Educ., 719 So.2d 793 (Ala. 1998).

14. O'Connor v. Board of Educ. of Sch. Dist. 23, 449 U.S. 1301 (1980); North Haven Bd. of Educ. v. Bell, 456 U.S. 512 (1982); Franklin v. Gwinnett County Pub. Sch., 503 U.S. 60 (1992); NCAA v. Smith, 525 U.S. 459 (1999); Jackson v. Birmingham Bd. of Educ., 544 U.S. 167 (2005). 


\begin{tabular}{|c|c|c|c|c|c|}
\hline & $\begin{array}{c}\text { State Court } \\
\text { of Appeal }\end{array}$ & $\begin{array}{c}\text { State } \\
\text { Supreme } \\
\text { Court }\end{array}$ & $\begin{array}{c}\text { U.S. District } \\
\text { Court }\end{array}$ & $\begin{array}{l}\text { U.S. Court } \\
\text { of Appeal } \\
\end{array}$ & $\begin{array}{c}\text { Supreme } \\
\text { Court }\end{array}$ \\
\hline 1993 & & & 5 & 5 & \\
\hline 1994 & & & 3 & 2 & \\
\hline 1995 & & & 5 & & \\
\hline 1996 & 1 & & 4 & 1 & \\
\hline 1997 & & & 7 & 1 & \\
\hline 1998 & & 1 & 13 & 1 & \\
\hline 1999 & & & 8 & 5 & 1 \\
\hline 2000 & & & 7 & 2 & \\
\hline 2001 & & & 8 & 4 & \\
\hline 2002 & 1 & & 8 & 5 & \\
\hline 2003 & & & 4 & 1 & \\
\hline 2004 & 1 & & 10 & 1 & \\
\hline 2005 & & & 6 & 2 & 1 \\
\hline 2006 & 1 & & 8 & 5 & \\
\hline 2007 & 1 & & 9 & 4 & \\
\hline Totals & 7 & 1 & 130 & 47 & 5 \\
\hline
\end{tabular}

Another way to look at the results of this study is by looking at the level of sport involved in the cases. Cases separated into three distinct levels of sport participation, collegiate, high school, and other. The other category included cases dealing with issues at the junior high and elementary school level. With the incredible scrutiny of collegiate athletics it is not surprising that $57 \%$ of the cases found for this study, or 109 cases in all, dealt with issues at the collegiate level. It is more surprising to some that $38 \%$ of the cases (72) dealt with issues at the high school level. Although Title IX issues are not as well known or discussed involving high schools and high school athletes, this study clearly shows that the fight for equality begins before college for many. Finally, only 9 cases (5\%) were in the junior high or elementary school level. Although there may be Title IX problems even at these lower levels of athletic participation, there is little litigation at this level, perhaps demonstrating that litigants wait until the athletes involved are in high school where this study found 72 cases, to bring these issues to court.

Although the particular claims and outcomes discussed in the results section focused on each decade, it is also interesting to look at some overall numbers in these areas.

The percentages of cases involving the ten types of claims found in this study: 
1. Program inequalities (equal opportunity) $=22 \%$ ( 41 cases)

2. Employment discrimination $=19 \%$ (37 cases)

3. Sexual harassment claim against a coach or school $=11 \%(20.5$ cases $\left.^{15}\right)$ \& Peer sexual harassment claims $=11 \%$ (21.5 cases)

4. Other (a catchall for remaining claims) $=9 \%$ (17 cases)

5. Accommodation issues (interests and abilities) $=7 \%$ (13 cases) \& Elimination of boys teams or opportunities $=7 \%$ (12.5 cases)

6. Exclusion of girls from boys teams $=6 \%$ (11 cases)

7. Elimination of girls teams $=4 \%$ (8.5 cases) \& Exclusion of boys from girls teams $=4 \%$ (8 cases)

With so much focus in scholarship and the media on program inequities and the lack of opportunities for women in sports, it is particularly interesting that the second most litigated claim area involved employment discrimination issues not related to participation opportunities for athletes.

Finally, the percentages of cases reaching the seven outcomes categorized in the cases found in this study were as follows:

1. Motion - claims proceed / remand $=29 \%$ (56 cases)

2. Motion for summary judgment granted / Claim dismissed (claim ends with no Title IX violation found) $=22 \%$ (41 cases)

3. Other $=19 \%$ (36 cases)

4. Motion- claims dismissed (no Title IX decision) $=9 \%$ (17 cases) \& Title IX violation $=9 \%$ (18 cases)

5. Motion for summary judgment granted / Claim dismissed (claim ends with Title IX violation found) $=6 \%$ (11 cases) \& No Title IX violation $=6 \%$ (11 cases $)$

This demonstrates that courts are often faced with multiple motions by the parties involved, and the losing party will usually appeal. This is clearly represented by the $29 \%$ of cases where the result was a remand of the case to a lower court so that the claims proceeded further.

It is also interesting to note that out of the 190 cases in this study only 29 cases, or $15 \%$, found a violation of Title IX. As many of the cases did not reach a decision related to an analysis of a particular violation (i.e. cases where claims were allowed to proceed but no decision was made on a violation), this

15. Categories with half numbers include cases that brought two distinct claims. 
percentage may seem a bit low. However, even out of the 81 decisions that included a specific holding related to a Title IX violation, only $35 \%$ of the cases found an actual violation of the law.

\section{By Decade}

Beyond the overall information found in this study, this analysis will now shift to an analysis of the results found in each decade covered. This analysis will include a discussion of important cases and developments in the particular decade and a look at the particular claims and outcomes of the cases found.

\section{$1970 s$}

Although Title IX was passed by Congress on June 23, 1972, beyond its blanket provision mandating protection from discrimination for both sexes, the law did not provide clear guidance as to how to enforce this mandate. During the remaining years of the 1970s, there were only seven cases dealing with Title IX within the athletic context. Although cases as early as 1973 mentioned this new federal law, it was not until 1976 that the first case involving athletics was litigated. ${ }^{16}$ Instead, the 1970 s were marked by several significant developments from the federal government.

\section{Important Developments and Cases}

Section 1682 of Title IX provided that the federal agencies responsible for providing federal financial assistance to schools and other educational programs, were also responsible for issuing rules and other guidance to "effectuate the provisions" of Title IX. ${ }^{17}$ However, for the first two years of the existence of the statute, no agency took action.

Finally, the Education Amendments of 1974 provided that the Secretary of the Department of Health, Education, and Welfare (now known as the Department of Education) had to publish regulations implementing the provisions of Title IX. ${ }^{18}$ These regulations were finished in June of 1974 and were finally published in $1975 .^{19}$

The regulations begin with a prohibition against discrimination almost mirroring Title IX:

\footnotetext{
16. Cape, 424 F.Supp. 732.

17. 20 U.S.C. $\$ 1682$ (2007).

18. Education Amendments of 1974, P.L. 93-380, 88 Stat. 612 (1974).

19. Athletics, 34 C.F.R. 106.41 (2007).
} 
No person shall, on the basis of sex, be excluded from participation in, be denied the benefits of, be treated differently from another person or otherwise be discriminated against in any interscholastic, intercollegiate, club or intramural athletics offered by a recipient, and no recipient shall provide any such athletics separately on such basis. ${ }^{20}$

This general provision is then augmented with the regulations focus on "equal opportunity for both sexes" in any high school, college or intramural sport. ${ }^{21}$ In order to assess this equal opportunity and to provide some guidance for schools and for the Department as it evaluates schools, the regulations then provide ten factors that are used to assess whether a particular program provides equal opportunity for both sexes:

(1) Whether the selection of sports and levels of competition effectively accommodate the interests and abilities of members of both sexes;

(2)The provision of equipment and supplies;

(3) Scheduling of games and practice time;

(4) Travel and per diem allowance;

(5) Opportunity to receive coaching and academic tutoring;

(6) Assignment and compensation of coaches and tutors;

(7) Provision of locker rooms, practice and competitive facilities;

(8) Provision of medical and training facilities and services;

(9) Provision of housing and dining facilities and services;

(10) Publicity. ${ }^{22}$

The benchmark for Title IX compliance had been established, schools now had notice of specific expectations, and potential plaintiffs had grounds to establish a cause of action. However, there was very little litigation. One possible explanation is that the Regulations provided for an "adjustment period" that allowed elementary schools just one year to come into compliance, but gave three years for high schools, colleges and universities. ${ }^{23}$ Another is that individuals believed that the Office for Civil Rights (OCR)

\footnotetext{
20. 34 C.F.R. 106.4(a).

21. 34 C.F.R. 106.4 (c).

22. Id.

23. 34 C.F.R. 106.41(d).
} 
would proactively conduct investigations to determine whether schools were in compliance.

While female athletes across the country were demanding more opportunities and benefits, the National Collegiate Athletics Association (NCAA) was in court trying to have the regulations invalidated. ${ }^{24}$ The NCAA sued the Secretary of the Department of Health, Education and Welfare, claiming, among several claims, that the regulations were overbroad because intercollegiate athletic programs do not directly receive federal financial assistance and that the Department exceeded its authority in promulgating the regulations without making express findings that they were consistent with the objectives of each statute under which federal financial assistance could be awarded to educational institutions. ${ }^{25}$ The Department moved to dismiss and the court sustained the motion finding that because the NCAA is not the recipient of federal funds, Title IX does not directly apply to the association and the regulations impose no duties on the organization. ${ }^{26}$ Therefore, the court concluded that there was no justiciable case or controversy between the NCAA and the Department, nor was there a case or controversy that is ripe for judicial determination. ${ }^{27}$

Even with the regulations in place, interested parties still did not understand how to follow the regulations in order to enforce the mandates of Title IX. As a result, in 1979, OCR issued a Policy Interpretation targeted at intercollegiate athletics programs, though specifically applicable to high school, intramural and club sports. ${ }^{28}$ The purpose of the policy interpretation was to explain the regulations, to provide a framework to resolve Title IX complaints and to provide additional guidance for institutions on the requirements for compliance with Title IX in intercollegiate athletic programs. The interpretation then intends to clarify the meaning of "equal opportunity" from the regulations. It also provides the factors and standards from Title IX and the regulations to be used in determining whether an intercollegiate athletics program is in compliance.

The policy interpretation is separated into three distinct areas:

\footnotetext{
24. See, NCAA, 444 F.Supp. 425.

25. Id. at 429 .

26. Id. at $430-431$.

27. Id. at 437 .

28. Title IX of the Education Amendments of 1972; A Policy Interpretation; Title IX and Intercollegiate Athletics, 44 Fed. Reg. at 71,423 (Dec. 11, 1979), available at http://www.ed.gov/about/offices/list/ocr/docs/t9interp.html [hereinafter "Policy Interpretation"].
} 
1. Compliance in Financial Assistance (Scholarships) Based on Athletic Ability: Pursuant to the regulation, the governing principle in this area is that all such assistance should be available on a substantially proportional basis to the number of male and female participants in the institution's athletic program.

2. Compliance in Other Program Areas (Equipment and supplies; games and practice times; travel and per diem, coaching and academic tutoring; assignment and compensation of coaches and tutors; locker rooms, and practice and competitive facilities; medical and training facilities; housing and dining facilities; publicity; recruitment; and support services): Pursuant to the regulation, the governing principle is that male and female athletes should receive equivalent treatment, benefits, and opportunities.

3. Compliance in Meeting the Interests and Abilities of Male and Female Students: Pursuant to the regulation, the governing principle in this area is that the athletic interests and abilities of male and female students must be equally effectively accommodated. $^{29}$

The focus of the litigation reported in this study is on parts two and three of the regulations.

Part two, dealing with "Compliance in Other Program Areas" focuses on assessing equal opportunity in the provision of the second through tenth factors provided in the regulations. Each of these factors is then analyzed using a four step process. The first step calls for an assessment of each individual factor by comparing the availability, quality and kinds of benefits, opportunities, and treatment afforded members of both sexes. ${ }^{30}$ Next, if there are inequalities, the Department will look at any nondiscriminatory factors that may account for the disparity. ${ }^{31}$ If a disparity is still apparent, the third step provides for individual criteria used to evaluate the nine factors from the regulations. For instance, in assessing the factor of "Scheduling of Games and Practice Times," ${ }^{32}$ the policy interpretation provides that the following criteria must be analyzed:
29. Id.
30. Id.
31. Id.
32. 36 C.F.R. 106.41(c)(3). 
(1) The number of competitive events per sport

(2) The number and length of practice opportunities

(3) The time of day competitive events are scheduled

(4) The time of day practice opportunities are scheduled; and

(5) The opportunities to engage in available pre-season and postseason competition. ${ }^{33}$

Finally, the fourth step provides an overall assessment of compliance by evaluating

(a) Whether the policies of an institution are discriminatory in language or effect, or

(b) Whether disparities of a substantial and unjustified nature exist in the benefits, treatments, services, or opportunities afforded male and female athletes in the institution's program as a whole, or

(c) Whether disparities in benefits, treatment, services, or opportunities in individual segments of the program are substantial enough in and of themselves to deny equality of athletic opportunity. ${ }^{34}$

This four step process used to assess "Compliance in Other Program Areas" has become particularly important in the many cases dealing with scheduling and facility issues in high school athletics.

The other part of the policy interpretation that has been the focus of much of the litigation and scholarship within the area is part three dealing with "Compliance in Meeting the Interests and Abilities of Male and Female Students." Although this part provides many other factors and tests used to assess compliance in this area, ${ }^{35}$ no test has received more publicity than the three part effective accommodation test:

33. Policy Interpretation, supra note 34.

34. Id.

35. For instance there is another test used to assess equal opportunity in the selection of sports. This test assesses

(1) Whether the competitive schedules for men's and women's teams, on a program-wide basis, afford proportionally similar numbers of male and female athletes equivalently advanced competitive opportunities; or (2) Whether the institution can demonstrate a history and continuing practice of upgrading the competitive opportunities available to the historically disadvantaged sex as warranted by developing abilities among the athletes of that sex.

Id. 
1) Whether intercollegiate level participation opportunities for male and female students are provided in numbers substantially proportionate to their respective enrollments; or

(2) Where the members of one sex have been and are underrepresented among intercollegiate athletes, whether the institution can show a history and continuing practice of program expansion which is demonstrably responsive to the developing interest and abilities of the members of that sex; or

(3) Where the members of one sex are underrepresented among intercollegiate athletes, and the institution cannot show a continuing practice of program expansion such as that cited above, whether it can be demonstrated that the interests and abilities of the members of that sex have been fully and effectively accommodated by the present program. $^{36}$

This test has become the focal point of the media, special interest groups, and the courts over the past 28 years.

Even given this framework of regulation, for the first few years after the enactment of Title IX courts did not allow plaintiffs to bring claims under the statute. In fact, in the first two cases found in this study, the courts held that the plaintiffs, female student athletes, could not bring a private claim under Title IX because no private right of action was provided by that statute. ${ }^{37}$ It was not until 1979, coincidentally the same year that the Policy Interpretation was enacted, that this changed.

In Cannon v. University of Chicago a student sued claiming that she was denied admission to medical school based on her sex in violation of Title IX. ${ }^{38}$ The district court granted the school's motions to dismiss finding that the statute did not authorize a private right of action for a person claiming to be injured under the statute. ${ }^{39}$ The United States Court of Appeals for the Seventh Circuit affirmed. ${ }^{40}$ The Supreme Court found that a woman who was denied admission to an educational program of a federally funded program, on the basis of sex, was exactly the type of individual who should be able to seek

36. Id.

37. Cape, 424 F. Supp. at 738; Jones v. Oklahoma Sec. Sch. Activities Assoc., 453 F. Supp. 150, 153-154 (W.D. Okla. 1977).

38. Cannon v. University of Chi., 99 S.Ct. 1946 (1979).

39. Cannon v. University of Chi., 406 F.Supp. 1257 (N.D. Ill. 1976).

40. Cannon v. University of Chi., 559 F.2d 1063 (7th Cir. 1976). 
protection under Title IX. ${ }^{41}$ Therefore, notwithstanding the absence of specific language authorizing a private right of action within the statute, the Court found that the student could maintain her lawsuit because the Court implied a private cause of action under Title IX for such aggrieved individuals. ${ }^{42}$

Results for the 1970s

This study found only seven cases in the 1970s. One of those cases found a violation of Title IX, ${ }^{43}$ and even the one case that found no violation of the statute did so because the court found no private right of action to enforce Title IX. ${ }^{44}$ Obviously, after the Cannon decision this type of result has changed.

In the end, perhaps no decade has seen more significant developments than the 1970s. During the 1970s Title IX was enacted, the regulations and policy interpretation were put forth and the Supreme Court found that a private litigant can bring a claim under Title IX. Every attorney, scholar and litigant must understand these early developments in order to understand gender equity law today.

$1980 s$

Once the Supreme Court established that there was a private right of action that could be used to enforce the provisions of Title IX, the next decade saw an explosion of litigation.

\section{Important Developments and Cases}

Although individuals could now sue to enforce Title IX, there was confusion as to who could be sued. The problem was that courts were inconsistent as to what was a program receiving "federal financial assistance" as required under the law. ${ }^{45}$ The culmination of the issue was in a case that made its way to the United States Supreme Court in 1984.

41. Cannon, 99 S.Ct. 1946.

42. Cannon, 99 S.Ct. at 1965-1966.

43. Gomes v. Rhode Island Interscholastic League, 469 F. Supp. 659 (D.R.I. 1979) (court held that boys must be able to play on the girls teams).

44. Jones, 453 F. Supp. 150 (plaintiff's motion for summary judgment denied because there is no private right of action under Title IX).

45. 20 U.S.C. $\S 1681$. 
In Grove City College v. Bell, a private college refused to execute an assurance of compliance with Title IX because it did not directly receive federal funding. ${ }^{46}$ Students at the college received federal financial aid in the form of Basic Educational Opportunity Grants (BEOGs). The Department of Education declared that the college was a recipient of federal financial assistance and initiated administrative proceedings to declare the college as well as its students ineligible for federal funding, including BEOGs. ${ }^{47}$ The Supreme Court held that Title IX did apply to the college because its students received BEOGs. Specifically, the Court declared that the college's financial aid program, and not the entire college, was the program or activity that received federal funding, and therefore BEOGs could be terminated because the college had refused to execute an assurance of compliance with Title IX. ${ }^{48}$

Under the Grove City College decision, unless the athletic department directly received federal funding, it did not have to comply with Title IX. In the next three years, five courts found that a Title IX claim could not be brought due to this lack of specific departmental financial funding. ${ }^{49}$

In response to these cases, and seeking to restore Title IX to its intended focus, Congress passed the Civil Rights Restoration Act on March 22, 1988..$^{50}$ The Act enumerates that Title IX should be interpreted through an institution wide, rather than program specific, approach. Specifically in reference to schools, the Act provides that "the term 'program or activity' and 'program' mean all of the operations of- - . . . (2)(A) a college, university, or other postsecondary institution, or public system of higher education. ${ }^{51}$ Therefore, instead of focusing merely on the particular athletic department involved, if any part, program, or department of a college or university accepts federal funding then the athletic department is subject to Title IX.

\section{Results for the 1980s}

Even after the enactment of the Civil Rights Restoration Act, there were no Title IX cases in 1989. Still, on the whole, the 1980s saw three times as

46. Grove City Coll., 465 U.S. 555.

47. Id. at 560 .

48. Id.

49. O'Connor v. Peru St. Coll., 605 F. Supp. 753 (D. Neb. 1985); Lantz v. Ambach, 620 F. Supp. 663 (S.D.N.Y. 1985); O'Connor v. Peru St. Coll., 781 F.2d 632 (8th Cir. 1986); EEOC v. Madison Comm. Unit Sch. Dist., 43 Fair Empl. Prac. Cas. (BNA) 1410 (1987); Bennett v. West Tex. State Univ., 799 F.2d 155 (5th Cir. 1986)

50. Civil Rights Restoration Act, 20 U.S.C. § 1687 (2007).

51. Id. $1687(2)(\mathrm{A})$. 
many cases as the 1970s. During the 1980s courts also began to review claims of employment discrimination under Title IX. ${ }^{52}$ The majority of the cases during this decade $(56 \%=14$ cases) ended without any decision related to an alleged violation of Title IX. ${ }^{53}$ Advocates and student athletes had to wait until the 1990s to see the true impact of the Civil Rights Act on Title IX litigation.

1990s

The first real spike in litigation involving Title IX and athletics occurred in the 1990s, two decades after the enactment of the law.

\section{Important Developments and Cases}

In 1990, OCR issued the Title IX Investigators Manual. ${ }^{54}$ This is the manual that an OCR investigator should use while conducting a Title IX compliance audit of a covered program or entity. The manual provides a clear, consistent direction for investigators to conduct a thorough investigation from receipt of a complaint through the issuance of a letter of findings. It includes 13 sections that examine each of the program components from the regulations and policy interpretation that may be investigated in athletics departments. Appendices that provide models for investigative plans, data requests, forms and explanation of statistical analysis complete the manual. ${ }^{55}$

In 1992, the Supreme Court's decision in Franklin v. Gwinnett County Public Schools, significantly strengthened a plaintiff's rights under Title IX. ${ }^{56}$ Christine Franklin was a student at North Gwinnett High School who was subjected to continual sexual harassment for two years by Andrew Hill, a teacher and coach. ${ }^{57}$ The school was notified of Hill's behavior and investigated, but took no action to stop it. ${ }^{58}$ They also discouraged Franklin from pressing charges against Hill. ${ }^{59}$ Hill resigned on the condition that all

52. See, e.g., Strong v. Demopolis City Bd. of Educ., 515 F. Supp. 730 (S.D. Ala. 1981).

53. In these cases claims were dismissed without any particular decision related to Title IX or the cases were allowed to proceed or remanded on the Title IX claims.

54. VAlerie Bonnette \& Lamar Daniel, Title IX InVestigators Manual, United States Department of Education, Office for Civil Rights (1990).

55. Id.

56. Franklin, 503 U.S. 60.

57. Id. at 63 .

58. Id.

59. Id. 
matters pending against him be dropped and the school closed its investigation. ${ }^{60}$ At issue on appeal was the availability of monetary damages for a plaintiff under Title IX. The Supreme Court explained that the availability of all appropriate remedies is presumed unless Congress has expressly indicated otherwise. ${ }^{61}$ The holding that a damages remedy is available for an action brought to enforce Title IX ${ }^{62}$ significantly strengthened the incentive for those student-athletes harmed by sex discrimination to file a private law suit rather than lodge a complaint with the OCR.

On January 16, 1996, OCR released its "Clarification of Intercollegiate Athletics Policy Guidance: The Three-Part Test." ${ }^{63}$ The 1996 Clarification provided an updated interpretation and clarification of the three part test by making clear that it provides schools with three separate ways to provide nondiscriminatory opportunities for both sexes. ${ }^{64}$ As to the first part of the test focusing on substantial proportionality, the Clarification made clear that participation opportunities must be substantially proportionate to enrollment and that a school must count all athletes receiving some benefits. ${ }^{65}$ Perhaps most important, it also made clear that schools could choose to cap or eliminate opportunities for the overrepresented sex in order to comply with this test. This issue only appeared in the litigation found for this study in the 1990s starting with the Kelley v. Board of Trustees and Gonyo v. Drake University, decisions in $1993 .{ }^{66}$ Although advocates for male sports have consistently lost in their claims about lost male opportunities, the litigation has continued since 1993, even after this Clarification showed that elimination of opportunities for male athletes can often be a viable way to comply with Title IX.

As to the second part of the test focusing on a history and practice of program expansion, the Clarification showed that schools must be responsive to projected female interests in addition to the interests of enrolled students, and that in order to meet this test they must be able to demonstrate the addition and elevation of sports in response to the needs and interests of

60. Id. at 64 .

61. Id. at 66 .

62. Id. at 76 .

63. United States Department of Education, Office for Civil Rights, Clarification of Intercollegiate Athletics Policy Guidance: The Three-Part Test (Jan. 16, 1996), available at http://www.ed.gov/about/offices/list/ocr/docs/clarific.html.

64. Id.

65. Id.

66. Kelley v. Bd. of Tr., 832 F. Supp. 237 (C.D. Ill. 1993); Gonyo v. Drake Univ., 837 F. Supp. 989 (S.D. Iowa 1993). 
underrepresented sex. ${ }^{67}$ However, OCR will not find a history and continuing practice where a school increases proportional participation for women (the underrepresented sex) by reducing opportunities for men (the overrepresented sex) alone or by reducing both but men more.

Finally, in regard to the third part of the test focusing on full and effective accommodation of the interests and abilities of the underrepresented sex, the Clarification showed that this analysis must include admitted students not yet enrolled but not potential future students and that even if men are overrepresented a school still may not face any problems if it can show women are not interested in participating in sports. ${ }^{68}$ This is one of the most controversial aspects of the three part test and will be the focus of further clarifications from OCR. OCR also provided several considerations it will undertake when analyzing whether there is unmet interest at a particular school, including participation at the club and intramural level, participation at the high school and recreational league level in the area and the experience of participants to determine whether they could sustain a team in the particular sport. $^{69}$

While OCR was clarifying the role of the effective accommodation test in Title IX compliance, the First Circuit was establishing precedent in the landmark case, Cohen v. Brown University. ${ }^{70}$ In 1991, Brown University dropped four sports, women's volleyball and gymnastics and men's golf and water polo because of budget restrictions. The female student-athletes sued for reinstatement of their teams. ${ }^{71}$ This First Circuit decision provided an indepth analysis of the history of Title IX, the statutory framework, and the role of the regulation, policy interpretation, and 1996 Clarification. The court specifically stated that the regulation "deserves controlling weight" and that the policy interpretation "warrants substantial deference . . . because the agency's rendition stands upon a plausible, if not inevitable, reading of Title IX. $^{72}$ The court also relied on the Clarification for its examples demonstrating how schools may meet the requirements of the three part test. ${ }^{73}$

\footnotetext{
67. Id.

68. Id.

69. Id.

70. Cohen v. Brown Univ., 101 F.3d 155 (1st Cir. 1996).

71. Cohen v. Brown Univ., 809 F. Supp. 978 (D. R.I. 1992).

72. Cohen, 101 F.3d at 167 (citing Cohen v. Brown Univ., 991 F.2d 888, 896-899 (1st Cir.

73. Id. at 167 .
} 1993)). 
The primary focus of the court's analysis is on Brown's failure to effectively accommodate the interests and abilities of its students, and in analyzing the impact of that failure the court dissects the requirements for measuring effective accommodation. ${ }^{74}$ In doing so, early on in this litigation the court identified the first prong of the three part test focused on proportionality as a "safe harbor, as it explained that "a university which does not wish to engage in extensive compliance analysis may stay on the sunny side of Title IX simply by maintaining gender parity between its student body and its athletic lineup., ${ }^{75}$ This rationale has since pervaded the Title IX mentality of athletics administrators, often resulting in the elimination of men's programs without creating any opportunities for women in order to achieve compliance. However, the court also made clear, in following the 1996 Clarification that the school's "proposal to cut men's teams is a permissible means of effectuating compliance." ${ }^{76}$

On the sexual harassment front, in 1997, OCR developed its "Sexual Harassment Guidance: Harassment of Students by School Employees, Other Students, or Third Parties." ${ }^{77}$ The manual explains that sexual harassment is discrimination based on sex that is prohibited under Title IX and that schools are required to have grievance procedures through which students can complain of alleged sex discrimination, including sexual harassment. ${ }^{78}$ The 1997 Guidance provided definitions of both quid pro quo ${ }^{79}$ and hostile environment sexual harassment ${ }^{80}$ are defined and addressed. ${ }^{81}$ Specifically, schools are always liable for quid pro quo harassment, while they can be liable for hostile environment harassment if the employee acts with apparent authority that aids in pervading the harassment. ${ }^{82}$ Schools also may be liable for peer to peer sexual harassment if a hostile environment exists in a school's programs or activities, the school knows or should have known of the

\footnotetext{
74. Cohen, 101 F.3d 166.

75. Cohen, 991 F.2d at $897-898$.

76. Cohen, 101 F.3d at 188.

77. United States Department of Education, Office for Civil Rights, Sexual Harassment Guidance: Harassment of Students by School Employees, Other Students, or Third Parties, 4000-01-P (1997), available at http://www.ed.gov/about/offices/list/ocr/docs/sexhar00.html.

78. Id.

79. Where a coach grants or withholds benefits as a result of the athlete's willingness or refusal to submit to the coach's sexual demands.

80. Where the conduct is so severe that it creates an intimidating, hostile or offensive environment that interferes with the athlete's ability to perform.

81. Id.

82. Id.
} 
harassment, and the school fails to take immediate and appropriate corrective action. ${ }^{83}$ In the end, to deal with all forms of sexual harassment schools must establish grievance procedures, provide for prompt and equitable resolution of sex discrimination complaints, publicize the procedures and full sexual harassment policy, monitor employees to avoid vicarious liability, and after notice of possible harassing conduct a school must take immediate and appropriate steps.

At the end of the 1990s, two very important Supreme Court cases added to this focus on combating sexual harassment. In 1998, in Gebser v. Lago Vista Independent School District, the Court showed that a student can sue for monetary damages for a teacher's (and therefore a coach's) sexual harassment if a school official who has authority to address the harassment is deliberately indifferent in responding to it. ${ }^{84}$ Gebser engaged in a sexual relationship with one of her teachers. The relationship was never reported to school officials. ${ }^{85}$ When the school district discovered the couple having sex, the teacher was arrested and eventually terminated. ${ }^{86}$ Although the school district had failed to establish an anti-harassment policy and had not distributed an official grievance procedure as required by federal regulations, Gebser was not able to recover damages because she failed to prove that an employee with supervisory power over the offending employee actually knew of the abuse, had the power to end it, and failed to do so. ${ }^{87}$ Although this is not a sportsrelated case, it establishes the standard of liability for sexual relationships between students and school employees and provides another outlet for students seeking relief from sexual harassment.

In 1999, the Supreme Court further expanded the scope of sexual harassment protection under Title IX, holding that there is a private cause of action under Title IX for individuals who suffer from student-on-student, or peer harassment. ${ }^{88}$ In Davis, a fifth grader was the victim of prolonged sexual harassment by a fifth grade classmate. The student complained about the offensive behavior to the classroom teacher, the physical education teacher,

83. Id.

84. Gebser v. Lago Vista Indep. Sch. Dist., 524 U.S. 274 (1998). Because this case does not involve athletics, it is not included in the overall numerical results for this study.

85. Id.

86. Id.

87. Id.

88. Davis v. Monroe County Bd. of Educ., 526 U.S. 629 (1999). Because this case does not involve athletics, it is not included in the overall numerical results for this study. 
and a third teacher over the course of several months. ${ }^{89}$ The harassment stopped only when the harasser was arrested and pled guilty to sexual battery for his behavior. ${ }^{90}$ School officials did nothing to address the situation, even while the victim's grades fell and she contemplated suicide ${ }^{91}$ The Supreme Court held that the student has an implied right of action under Title IX when the sexual harassment is so severe, pervasive, and objectively offensive that it effectively bars the victim's access to an educational opportunity or benefit. ${ }^{92}$ The institution was liable for damages when school officials acted with deliberate indifference to known acts of harassment in its programs or activities. ${ }^{93}$

Results for the 1990s

Overall, the 1990s saw an incredible spike in Title IX litigation, especially in the latter half of the decade with almost as many cases in the five year period from 1995 to 1999 (48 cases) as there were from the enactment of Title IX in 1972 to 1994 (53 cases), a 23 year period.

After the Franklin decision, Title IX litigation saw its first large spike in litigation with 24 decisions from the end of 1992 until 1995. Interestingly, until the end of 1995, only three of the 58 cases found for this study in that time period focused on the three part effective accommodation test, ${ }^{94}$ the test that now seems to be the focus of most of the litigation and scholarship surrounding Title IX. The 1990s also saw the first cases brought claiming that the elimination of men's opportunities violated Title IX $\left(7.5\right.$ cases $\left.^{95}\right)$, the first claims for sexual harassment by coaches (6 cases) and peer sexual harassment ( 3 cases), and the first cases to focus extensively on accommodation and the three part test (7 cases).

After the Clarification and the First Circuit's 1996 decision in the Cohen case, Title IX litigation spiked again until the end of the 1990s. From 1997 to 1999 the courts reviewed 37 cases. While a few of these cases continued the

89. Id. at 633 .

90. Id. at 634 .

91. Id.

92. Id. at 653 .

93. Id.

94. Cook v. Colgate Univ., 802 F. Supp. 737 (N.D.N.Y. 1992), vacated, remanded, 992 F.2d 17 (2d Cir. 1993); Horner v. Kentucky High Sch. Athletic Ass'n, 43 F.3d 265 (6th Cir. 1994).

95. The Lichten v. State University case included claims focused on the elimination of both men's and women's teams and so it is included in both categories of claims resulting in the half number of cases. 646 N.Y.S.2d 402 (N.Y. App. Div. 1996). 
trend of men suing due to the elimination of their teams or opportunities, ${ }^{96}$ the majority of the remaining cases in this decade focused on sexual harassment issues (nine cases), program inequalities as analyzed under the regulations and policy interpretation (13 cases) and employment discrimination (19 cases).

The 1990s also saw a significant increase in cases wherein courts found a Title IX violation. In the 1970s and 1980s, only two courts found clear violations of the statute. Of course, much of this is due to the lack of understanding of the law before the Cannon decision and the enactment of the Civil Rights Restoration Act. However, during the decade that saw the publication of the 1996 Clarification and the Supreme Court's Franklin, Gebser and Davis decisions, there were 19 cases wherein a court found a violation of Title IX. On the other hand, there were 22 cases wherein the courts found no violation of the statute. In the end, the stage was seemingly set for the 2000s and further scrutiny of schools and other educational programs under Title IX.

$2000 s$

Although this research was completed in 2007, the results for the current decade still contain more cases than any other. This spike in litigation has mirrored a spike in guidance, clarifications and other developments surrounding Title IX.

\section{Important Developments and Cases}

The first major development of the decade happened in 2001 when OCR issued its "Revised Sexual Harassment Guidance: Harassment of Students by School Employees, Other Students, or Third Parties." ${ }^{97}$ The Revised Guidance was a response in part to the Supreme Court's Gebser and Davis decisions. Whereas those cases established the liability standards for private actions and monetary damages for sexual harassment of students under Title IX, the Revised Guidance reiterates that OCR is responsible for enforcing Title IX compliance. It also provides the principles that a school should use to recognize and effectively respond to sexual harassment of students, even in circumstances that would not give rise to a claim for monetary damages. ${ }^{98}$

96. See, e.g., Neal v. Board of Tr., 198 F.3d 763 (9th Cir. 1999).

97. Revised Sexual Harassment Guidance: Harassment of Students by School Employees, Other Students, or Third Parties, 66 Fed. Reg. 5512 (Jan. 19, 2001), available at http://www.ed.gov/ legislation/FedRegister/other/2001-1/011901b.html [hereinafter "Revised Guidance"].

98. Id. 
Also in 2001, the Government Accounting Office released its reports on "Intercollegiate Athletes: Four-Year Colleges' Experiences Adding and Discontinuing Teams." 99 The report was based on a questionnaire sent to NCAA and National Association of Intercollegiate Athletics (NAIA) schools. Perhaps most significant was the report's analysis of schools that had cut teams. The report found that since 1992-1993, 386 teams were cut for men, while 150 were cut for women. However, contrary to male advocates who began to sue over the issue in the 1990s, the report found that $72 \%$ of schools were able to add women's teams without cutting men's teams; instead they relied on revenue from other sports or outside sources to finance the new teams and did not simply cut men's opportunities to save money. This particular finding has been repeatedly contested by male advocates. ${ }^{100}$

2002 marked the thirtieth anniversary of Title IX and the Secretary of Education marked the occasion by creating a Commission on Opportunity in Athletics to study Title IX. The stated purpose of the Commission was to collect information, analyze issues, and obtain broad public input directed at improving the application of current federal standards for measuring equal opportunity for both genders to participate in school sponsored athletics programs. ${ }^{101}$ The interests of the members of the Commission, its representatives, the information gathering process, selection of presenters at Town Meetings, and even the charge of the Commission have been widely criticized. ${ }^{102}$ The Commission issued a final report on February 28, 2003, including 23 recommendations, of which 15 were unanimously approved. ${ }^{103}$ A minority report was issued by two members of the Commission on the same day out of concern that minority views were not adequately expressed in the final Commission report. ${ }^{104}$

99. United States Government Accounting OfFice, No. 01-297, Intercollegiate Athletics: Four-YeAR COlleges' EXPERIENCES ADDING AND DisCONTINUING TEAMS (March 2001), available at http://www.gao.gov/new.items/d01297.pdf.

100. See, e.g., National Wrestling Coaches Ass'n v. United States Dep't of Educ., 263 F. Supp. 2d 82 (D.D.C. 2003).

101. The Secretary of Education's Commission on Opportunity in Athletics, "Open to All” Title IX at Thirty (Feb. 28, 2003), available at http://www.ed.gov/about/bdscomm/list/athletics/report.html [hereinafter "Open to All"].

102. Barbara Osborne, Title IX in the 21st Century, 14 MARQ. SPORTS L. REV. 141, 153-156 (2003).

103. Open to All, supra note 110 , at 4.

104. DONnA DE VARONA \& Julie Foudy, MinORITy Views ON THE REPORT OF THE COMMISSION ON OPPORTUNITY IN ATHLETICS 19 (Feb. 2003), available at http://www.womenssportsfoundation.org/binary-data/WSF_ARTICLE/pdf_file/944.pdf. 
Based on recommendations from the Commission's final report, in 2003 OCR issued a "Further Clarification of Intercollegiate Athletics Policy Guidance Regarding Title IX Compliance." ${ }^{105}$ The letter corrects the letter of transmittal for the 1996 Clarification that identified proportionality as a safe harbor and emphasizes that any of the three parts of the effective accommodation test under the 1979 Policy Interpretation can be used to show that a school is effectively accommodating the interests and abilities of both sexes. ${ }^{106}$ Further, it clarifies that nothing within Title IX regulations requires cutting or reducing teams to demonstrate compliance. ${ }^{107}$ The practice of cutting teams to achieve numerical proportionality is officially a disfavored practice as it is contrary to the spirit of Title IX to create opportunity. ${ }^{108}$ Finally, the letter promised that OCR will conduct an education campaign to explain each prong of the effective accommodation test as a viable means of compliance. $^{109}$

As promised, in 2005, OCR issued an "Additional Clarification of Intercollegiate Athletics Policy: Three-Part Test - Part Three." ${ }^{110}$ This Additional Clarification explained that of 130 institutions OCR investigated from 1992 to 2002, two-thirds complied with part three of the effective accommodation test, focusing on the interests and abilities of the students involved. ${ }^{111}$ The Additional Clarification also specified that under this part of the test an institution may provide fewer opportunities for one sex if the interests and abilities of enrolled and admitted students of the underrepresented sex are being fully and effectively accommodated. ${ }^{112}$ In addition, if a school complies with part one of the effective accommodation test (ie., it provides substantially proportionate opportunities to both sexes), it

105. United States Department of Education, Office for Civil Rights, Further Clarification of Intercollegiate Athletics Policy Guidance Regarding Title IX Compliance (July 11, 2003), available at http://www.ed.gov/about/offices/list/ocr/title9guidanceFinal.html.

106. Id.

107. Id.

108. Id.

109. Id.

110. United States Department of Education, Office for Civil Rights, Additional Clarification of Intercollegiate Athletics Policy: Three-Part Test - Part Three (March 17, 2005), available at http://www.ed.gov/about/offices/list/ocr/docs/title9guidanceadditional.html [hereinafter "Additional Clarification"].

111. Id.

112. Id. 
is not required to accommodate the specific interests of students of underrepresented sex. ${ }^{113}$

Since the policy interpretation was issued, schools had been surveying their students in order to assess their interests and abilities as required under the third part of the three part test. The Additional Clarification developed a new web-based prototype survey that schools can rely on as an acceptable method to measure student interests. ${ }^{114}$ If schools follow the steps provided in the Additional Clarification, administer the survey to all undergraduates or all students of the underrepresented sex, and then fulfill the interests and abilities found in the survey, there is a presumption of compliance with part three of the effective accommodation test. ${ }^{115}$ Therefore, if the school engages in a proper survey, it will meet part three unless there is a sport for the underrepresented sex that has unmet interest sufficient to sustain a varsity team in the sport, sufficient ability to sustain an intercollegiate team in the sport, and a reasonable expectation of intercollegiate competition for a team in the sport within the school's normal competitive region. ${ }^{116}$ In the alternative, if by using the survey method, a school finds that it has sufficient unmet interest and ability to sustain a team and reasonable expectations of intercollegiate competition in that sport within the school's competitive region, the school is under an obligation to create a varsity team or elevate a club or intramural sport. ${ }^{117}$

Whereas it was once presumed that proportionality was a safe harbor, some argue that this Additional Clarification makes the third part more significant than the others. Of particular importance to many Title IX advocates, the Additional Clarification places the burden of proof on OCR or on the plaintiff student athlete to show by a preponderance of the evidence that the institution is not in compliance with part three. ${ }^{118}$

In addition, the Additional Clarification allows schools who use the survey to count non-responses as lack of interest. This has been particularly controversial. Even though the Clarification "makes clear that a school must

113. Id.

114. Id.

115. Id.

116. Id.

117. Paul Anderson, REVIEW ESSAY: A Place on the Team: The Triumph and Tragedy of Title IX, 16 MARQ. SPORTS L.REV. 461, 466 (2006).

118. Additional Clarification, supra note 119. Since the decision in Favia v. Indiana University of Pennsylvania, 812 F. Supp 578, 584 (W.D. Pa. 1992), the burden of proof had been on the institution to prove that they met either the second or third prongs. 
receive a high level of responses, that the survey must be conducted on a periodic basis, and that schools cannot use the survey results to eliminate teams" ${ }^{119}$ many groups, including the NCAA, the Women's Sports Foundation, and even the members of the Secretary's Commission on Opportunity in Athletics have asked OCR to rescind this Additional Clarification.

Outside of the regulatory realm, another important development came through further litigation before the Supreme Court. Roderick Jackson was a high school teacher and coach who complained that his team was being treated unfairly. ${ }^{120}$ The administration failed to address the inequities, and instead Jackson started getting negative evaluations and was eventually removed from his coaching position. ${ }^{121}$ Jackson sued complaining that the school board violated Title IX when it retaliated against him for complaining about unequal treatment of the girls' basketball program. ${ }^{122}$ The district court dismissed the case for failure to state a claim because Title IX does not provide a private cause of action for retaliation. ${ }^{123}$

The United States Court of Appeals for the Eleventh Circuit affirmed the decision, and the Supreme Court granted certiorari to resolve a conflict in the Circuits as to whether Title IX does provide a private right of action for retaliation claims based on complaints about sex discrimination. ${ }^{124}$ In the end, the Supreme Court held that retaliation against a person who complains of sex discrimination is intentional discrimination on the basis of sex in violation of Title IX. ${ }^{125}$ The Court explains that "Retaliation is, by definition, an intentional act. It is a form of 'discrimination' because the complainant is being subjected to differential treatment . . . Moreover, retaliation is discrimination 'on the basis of sex' because it is an intentional response to the nature of the complaint: an allegation of sex discrimination." ${ }^{126}$ Therefore, plaintiffs can now sue for retaliation against them when they report violations of Title IX. Just as retaliation claims are growing in the business sector, Jackson provides hope for those who are afraid of speaking out against discrimination in their athletic programs for fear of losing their jobs.

\footnotetext{
119. Anderson, supra note 126 , at 466.

120. Jackson, 544 U.S. at 171.

121. Id. at 172.

122. Id.

123. Id.

124. Id.

125. Id. at 174 .

126. Id. at $173-174$.
} 
A final interesting case that came down during this decade is Cobb v. U.S. Department of Education. ${ }^{127}$ The case begin when several fathers of high school girls hockey players sued claiming that OCR was not diligent in monitoring the scheduling of girls' state championships in Minnesota. OCR reviewed the situation and though the girls played in an inferior facility than the boys, OCR did not find that this disparity was enough to be a violation of Title IX. The fathers sued claiming that OCR's process was flawed and that OCR should have found a violation of the law. ${ }^{128}$ This lawsuit was dismissed for lack of standing, but the litigation continued when the daughters themselves filed an amended complaint against the government. ${ }^{129}$ Ignoring the cases showing that individuals cannot sue the government under Title IX, the court found that a private right of action against OCR could be sustained when the funding agency itself is accused of acting to violate Title IX. ${ }^{130}$ Therefore, the government's motion to dismiss the girls Title IX claim was denied. ${ }^{131}$ Although this is only a district court level decision, if other courts follow the lead of this case, OCR may find itself subject to a flood of litigation, especially from representatives of eliminated male sports who have repeatedly failed in their attempts to sue the government claiming violations of Title IX.

\section{Results for the 2000s}

Although our analysis of the 2000s continues to evolve, as of the end of 2007, this study found more Title IX decisions (89 cases) during the current decade than in any other. In fact, the cases within this decade make up $47 \%$ of the entire cases found in this study.

Overall, although the focus of gender equity law in the 2000s has often been on OCR and its Commission and Clarifications, there has also been extensive litigation on every front. In the sexual harassment area, there have been 33 cases focusing on different claims of peer or coach sexual harassment. The next highest focus of litigation has been on program inequalities at the high school level, from scheduling of sports, ${ }^{132}$ to differences in facilities

127. Cobb v. U.S. Dep't of Educ., Civil File No. 05-2439 (MJD/ALB), 2006 U.S. Dist. LEXIS 39985 (D. Minn. 2006).

128. Id.

129. Cobb v. U.S. Dep't of Educ., 487 F.Supp.2d 1049 (D. Minn. 2007).

130. Id. at 1054 .

131. Id. at 1055.

132. See, e.g, Cmtys. for Equity v. Mich. High Sch. Ath. Ass'n, 459 F.3d 676 (6th Cir. 2006). 
offered for male and female participants. ${ }^{133}$ Finally, the 2000s has seen a continuation of claims for employment discrimination (13 cases), and a resurgence of claims focusing on accommodation and the three part test (13 cases) although no cases have yet focused on the 2005 Additional Clarification.

Perhaps it is not surprising given the contentious nature of Title IX litigation that the outcomes of $35 \%$ of the cases (31 cases) during this decade have been to let a claim proceed or to remand the case with no decision. In addition, during the current decade only eight decisions have found a Title IX violation, while 24 cases have found no violation of the law.

The 2000s have also seen stepped up claims involving the regulations and policy interpretation themselves, specifically focusing on the three part test. Twelve cases have focused on claims by advocates for male sports, in particular athletes whose teams have been eliminated. These claims have focused on the elimination of the team as a violation of Title IX $^{134}$ and on reviews of the regulations and policy interpretation itself. ${ }^{135}$ As could be expected, although there are no signs that these advocates will discontinue their litigation, these cases have not been successful.

\section{FUTURE TRENDS}

In predicting future trends related to Title IX litigation, there are several unknowns. Currently, female participation in school sports at the high school and college levels is holding steady, but there is very little growth. ${ }^{136}$ However, women's sports programs are losing ground in funding, ${ }^{137}$ which may trigger a renewed interest by the courts in Title IX compliance with the

133. See, e.g., Landow v. Sch. Bd. of Brevard County, 132 F. Supp. $2 d 958$ (D. Fla. 2000).

134. See, e.g., Miami Univ. Wrestling Club v. Miami Univ., 302 F.3d 608 (6th Cir. 2002).

135. See,e.g., Nat'l Wrestling Coaches Ass'n v. Dep't of Educ., 383 F.3d 1047 (D.C. Cir. 2004); College Sports Council v. Dep't of Educ., 465 F.3d 20 (D.C. Cir. 2006); Equity in Athletics, Inc. v. Dept. of Ed., 504 F. Supp. 2d 88 (D.C. Virg. 2007).

136. R. Vivian Acosta \& Linda Jean Carpenter, Women In Intercollegiate Sport: A longitudinal, National, Study, Thirty-One Year Update (2008), available at http://webpages.charter.net/ womeninsport/2008\%20Summary\% 20Final.pdf (last visited Jan. 24, 2008). In addition, from 19911992 to 2004-2005 men's participation levels increased at a higher level than women. UNITED STATES GOVERNMENT ACCOUNTING OFFICE, GAO-07-535, INTERCOLLEGIATE ATHLETICS: RECENT TRENDS IN TEAMS AND PARTICIPANTS IN NATIONAL COLLEGIATE ATHLETIC ASSOCIATION SPORTS (JULY 2007).

137. For information on funding see, United States Department of Education, Office of Postsecondary Education, Equity in Athletics Data Analysis Cutting Tool Website, available at http://ope.ed.gov/athletics/ (last visited Jan. 24, 2008). 
laundry list of factors provided in the 1975 regulations. ${ }^{138}$ To this point, cases dealing with these areas have focused on scheduling issues ${ }^{139}$ and facility comparisons at the high school level. ${ }^{140}$ Perhaps these cases have only been seen at the high school level to date because parents continue to seek to fight for their minor children's rights. At the college level, when students are emancipated from their parents, it is possible that they do not bring similar claims because they fear retaliation and do not want to lose their spot on the team.

There is also some uncertainty related to the ability of plaintiffs to recover monetary damages in an implied private action under Title IX due to the United States Court of Appeals for the Fourth Circuit's decision in Mercer v. Duke University. ${ }^{141}$ In 1995, Heather Sue Mercer was participating as a kicker on the football team at Duke University. When she kicked the game winning field goal in the spring blue-white game and attracted media attention, the head coach engaged in a pattern of intentional discrimination (harassment) against Mercer and eventually cut her from the team, even though Duke had a no-cut policy and no male football player had been cut before. Unlike many Title IX lawsuits where the plaintiffs seek reinstatement of their team, Mercer sought a declaratory judgment that Duke University had engaged in intentional discrimination in violation of Title IX. ${ }^{142}$

At trial, a jury found in favor of Mercer and she was awarded one dollar in compensatory damages and two million dollars in punitive damages. ${ }^{143}$ Because Mercer was the prevailing party, the district court awarded Mercer more than $\$ 380,000$ in attorney's fees and costs. ${ }^{144}$

Duke appealed, arguing that punitive damages were not available under Title IX. The Fourth Circuit agreed, holding that punitive damages were not available for private actions brought under Title IX. ${ }^{145}$ The court relied on the

138. 34 C.F.R. $106.4(\mathrm{c})(2-10)$

139. See, e.g., Cmtys. for Equity v. Mich. High Sch. Athletic. Ass'n, 459 F.3d 676 (6th Cir. 2006) (court found that high school association discriminated against girls by placing their sports in nonadvantageous season).

140. See, e.g., Mason v. Minn. State High Sch. League, 2003 U.S. Dist. LEXIS 23460 (D. Minn. 2003) (court found that High School League had discriminated against girls in the facilities used for boys and girls high school hockey championships); Landow, 132 F. Supp. 2d 958 (court found disparities in the facilities provided for girls softball in comparison to boys baseball).

141. Mercer v. Duke Univ., 401 F.3d 199 (4th Cir. 2004).

142. Id.

143. Id. at 201.

144. Id.

145. Mercer v. Duke Univ., 50 Fed. Appx. 643 (4th Cir. 2002). 
Supreme Court's decision in Barnes v. Gorman. ${ }^{146}$ The court reasoned that because Title IX is interpreted consistently with Title VI, the Barnes decision compelled them to vacate the punitive damages award. ${ }^{147}$ This decision may significantly weaken the benefit of litigating a Title IX claim, at least in the Fourth Circuit. The significance may be particularly acute in sexual harassment and retaliation claims. It will be interesting to see if any of the other circuits follow the Fourth Circuit's lead.

Title IX protection for sexual harassment continues to develop with legal maneuvering in several cases. Two cases that had been dismissed by a lower court have recently been revived by the Tenth and Eleventh Circuit Courts respectively, to address the issue of whether a university has liability for the sexual assault and/or rape of an individual by a student-athlete or recruit. Both cases have significance for determining the extent to which a university must monitor the conduct of its students.

In Simpson v. University of Colorado, two former students claimed that they had been raped at an off-campus party for football players and recruits in 2001. ${ }^{148}$ Similarly, in Williams v. Board of Regents of the University System of Georgia, a woman who was then a student at the university claims that a basketball player at the university invited her to his room where they engaged in consensual sex. ${ }^{149}$ The basketball player allegedly arranged for a Georgia football player to hide in the closet while the couple had sex, and after the basketball player left the room, the football player raped the woman. During the rape, the basketball player called a teammate who then came to the room and also raped and assaulted the woman. In both of these cases, the men accused of the assaults were not convicted of the criminal charges. However, the reinstated cases focus on the university responsibility under Title IX. While the Georgia case addresses the issue of institutional liability for the actions of private individuals, the Colorado case heads into uncharted territory exploring whether an off-campus party attended by recruits bears the indicia of an official athletics department program.

While the previously mentioned cases will help to define the parameters of an institution's liability for sexual harassment under Title IX, considerable

146. Mercer, 50 Fed. Appx. 643, 2002 WL 31528244, at*3 (citing Barnes v. Gorman, 536 U.S. 181 (2002).

147. Id.

148. Simpson v. Univ. of Colo., 500 F.3d 1170 (10th Cir. 2007). On December 5, 2007, Colorado University President Hank Brown announced that the university had settled the case with plaintiffs Lisa Simpson receiving \$2.5 million and Anne Gilmore receiving \$350,000. Letter from Hank Brown to CU Alumnus, Dec. 5, 2007.

149. Williams v. Board of Regents of the Univ. Sys. of Ga., 477 F.3d 1282 (11th Cir. 2007). 
attention has been focused on Jennings v. University of North Carolina to delineate what constitutes a hostile environment. ${ }^{150} \mathrm{~A}$ former student-athlete at the University of North Carolina at Chapel Hill filed a lawsuit against her coach, the general counsel at the university, and several others affiliated with the soccer team or athletics program. ${ }^{151}$ The complaint alleged that a variety of comments and actions by the head coach created a hostile environment. The district court granted summary judgment for the defendants stating that "the behavior alleged did not constitute severe, pervasive and offensive sexual harassment that deprived the student-athlete of her educational opportunities." 152 The United States Court of Appeals for the Fourth Circuit affirmed. ${ }^{153}$ However, in an unusual legal maneuver, the Fourth Circuit granted the plaintiff's petition for rehearing and rehearing en banc. ${ }^{154}$ At the en banc hearing, the court vacated summary judgment on the Title IX claim, the claim against the coach for sexual harassment, and the claim against the general counsel for sexual harassment based on supervisory liability. ${ }^{155}$ Of particular concern to the judges en banc were incidents involving the coach questioning student-athletes about their sexual activities. At trial, a jury will decide whether the coach's acts fall within the definition of sexual harassment and rise to the level of creating a hostile environment. If so, the issue of whether the plaintiff was denied the benefits of an educational program or activity will then be answered. The trial will also address the supervisory liability of the university counsel.

Another unknown is the potential protection offered under Title IX for sexual orientation discrimination. Title IX does not expressly prohibit discrimination on the basis of sexual orientation; however, OCR's Revised Sexual Harassment Guidance states that Title IX protects male and female students from opposite-sex and same-sex harassment by school employees, other students, and third parties such as visiting athletes. ${ }^{156}$ It also acknowledges that sexual harassment directed at gay or lesbian students that is sufficiently serious to limit or deny a student's ability to participate in or

150. Jennings v. University of North Carolina, 482 F.3d 686 (4th Cir. 2007)

151. Jennings v. University of North Carolina, 340 F. Supp. 2d 666 (M.D.N.C. 2004).

152. Id. at 675 .

153. Jennings v. University of North Carolina, 444 F.3d 255 (4th Cir. N.C.. 2006).

154. Jennings v. University of North Carolina, No. 04-2447, CA-99-400-1, 2006 U.S. App. LEXIS 32390 (4th Cir. 2006).

155. Jennings, 482 F.3d 686. A petition for writ of certiorari to the Supreme Court was filed in this case on July 7, 2007.

156. Revised Guidance, supra note 106, at 2-3. 
benefit from the school's program constitutes sexual harassment prohibited by Title IX, which would seem to allow a cause of action based on sexual orientation. ${ }^{157}$ Although precedent indicates a willingness of the courts to expand the scope of Title IX claims, ${ }^{158}$ they have not taken the final step to declare protection from harassment because of sexual orientation. Under Title VII, the courts have acknowledged a cause of action for failure to conform to gender stereotypes, but there are no Title IX cases to support expanding the scope of protection within educational programs or activities. ${ }^{159}$ The case filed by Jennifer Harris against Rene Portland and Penn State University had seemingly ideal facts to test this issue. Harris believed that her playing time was diminished and she was driven off the team because of the coach's expressed prohibition of lesbians on the team. Harris claimed that she was not a lesbian, but that her coach thought she was because of her hairstyle, clothing, and friendships. However, the case was settled before any precedent could be established. ${ }^{160}$

\section{CONCLUSION}

The purpose of this study was to document the evolution of gender equity law as interpreted by the courts and federal agencies since the enactment of Title IX in 1972 by focusing on litigation and important developments related to this important federal law. Overall, although most scholars, attorneys and advocates focus on the three part accommodation test and its analysis of the numbers of participants and their interests and abilities, this study showed that this test has only been the focus of 20 out of the 190 cases found, or $10.5 \%$ of the claims brought before the courts. The reality is that more claims are brought dealing with employment issues (37 cases $=19 \%$ ) and the many sexual harassment issues as noted in the last section (42 cases $=22 \%$ ). This does not demonstrate a lack of problems in the accommodation area; instead, it is evidence that perhaps we have only scratched the surface of this problem, especially at the high school level.

In addition, there is often a perception that schools and other educational programs always lose Title IX cases. However, the evidence from this study shows that that is clearly not the case. In one area, male athletes suing after

157. Id. at 3 .

158. See, e.g., Davis, 526 U.S. 629; Wills v. Brown Univ., 184 F.3d 20 (1st Cir. 1999); Doe v. Dallas Indep. Sch. Dist., 153 F.3d 211 (5th Cir. 1998); Ray v. Antioch Unified Sch. Dist., 107 F. Supp. 2d 1165 (N.D. Cal. 2000).

159. Bibby v. Philadelphia Coca Cola Bottling Co., 85 F. Supp. 2d 509 (E.D. Pa. 2000).

160. Harris v. Portland, Civ. No. 05-2648, 6 (M.D. Pa. 2005). 
their teams have been eliminated, schools and the Department of Education do consistently win, although this is not surprising given the consistency of the regulations, interpretation, and clarifications of Title IX over the years. Beyond this area though, the reality is that the largest percentage of cases brought, 38\% (73 cases), either end with the claims merely proceeding or claims being dismissed with no decision related to the particular Title IX claims involved. This is evidence of two developments.

Initially, Title IX litigation typically involves many motions, rehearings, and remands, and so a final decision does not come until after a lengthy litigation process. ${ }^{161}$ This may also be evidence that there is still a lack of understanding of the nuances and complexity of gender equity law. Many advocacy groups continue to ignore the regulations and policy interpretation and argue that the courts should not defer to these policies or to the several clarifications that have also been put forth. Courts also are often confused and do not understand how of all of these pieces work together. However, courts who have understood these nuances have repeatedly made clear that all of these documents must be taken together as part of the gender equity law put forth by the federal agency in charge of monitoring Title IX.

In addition, 22\% (41 cases) of the cases ended with a court granting a motion dismissing any Title IX claims, in general because the plaintiffs could not present enough evidence demonstrating a violation of the law, while, only 15\% of the 190 cases studied (29 cases) actually found a violation of Title IX. Clearly, although there is a lot of litigation in this area, courts still do not often find that the defendants involved have violated the federal law.

In the end, perhaps two basic conclusions can be made as a result of this study. First, it is clear that the amount of litigation surrounding Title IX continues to grow and at a very rapid pace. Even though this study only includes the first eight years of the 2000s, during that eight year span there have been $29 \%$ more cases than there were in the 1990s, 256\% more cases than in the 1980 s, and $1157 \%$ more cases than in the 1970 s. Presumably, this increase will continue over the remaining two years of this decade as the average amount of cases in this decade at 11.25 cases per year is already almost double the average of any other decade studied. ${ }^{162}$

Second, courts, plaintiffs and defendants continue to struggle in their understanding of the true impact of Title IX and OCR's regulations,

161. See infra note 8.

162. The average for the $1970 \mathrm{~s}$ is .875 . For the 1980 s the average is 2.5 . And the average for the 1990s is 6.9. As of January 23, 2008, there were already three Title IX cases for the current year that would have been included in this study. 
interpretation and clarifications. It remains to be seen if OCR will put forth further clarifications potentially adding to the confusion and debate. As courts continue to struggle to understand the full impact of the law, plaintiffs will continue to bring their claims in their attempts to receive equal treatment as mandated by Title IX. And if this continued diligence leads to better understanding of the law and clarity by courts as they interpret Title IX, hopefully, the inequalities that are apparent at so many levels of sports will continue to improve.

\section{ABOUT THE AUTHORS}

PAul M. Anderson is the Associate Director of the National Sports Law Institute and an Adjunct Associate Professor of Law. He earned his BA in economics and philosophy, cum laude and Phi Beta Kappa, from Marquette University and is a graduate of the Law School who received the first Joseph E. O'Neill scholarship for sports ethics. Professor Anderson teaches Topics in Advanced Legal Research - Sports Law, the Amateur Sports Law Workshop, Entertainment Law and the Selected Topics in Sports Law Seminar. He is the founder and chair of the Sports Law Alumni Association and received the 2003 Sports Law Alumnus of the Year Award. Professor Anderson is a former Editor-in-Chief and faculty co-advisor to the Marquette Sports Law Review, and the Editor of the Journal of Legal Aspects of Sport, and the SRLA Newsletter. He is the author of numerous articles and several books including Major League Leases: An Overview Of Major League Facility Leases And How They Are Negotiated (2001) (with William Miller). He is Chair of the Sports and Entertainment Law Section of the State Bar of Wisconsin, a member of the ABA's Forum on the Sports and Entertainment Industries, the Sports Lawyers Association, the Sport and Recreation Law Association, the International Association of Sports Law.

Barbara Osborne is an Associate Professor in Exercise and Sport Science, and an Adjunct Professor in Law at the University of North Carolina at Chapel Hill. She earned her B.A. in Communications from the University of Wisconsin-Parkside, M.Ed. in Sport Management from Boston University, and J.D. from Boston College Law School. Professor Osborne is licensed to practice in North Carolina and Massachusetts. Prior to her academic appointment at UNC, she worked for 14 years as an athletics administrator in intercollegiate athletics. She has also had experience as a coach, public relations coordinator, television sports commentator, publisher and sports information director. Professor Osborne was honored by the University of 
North Carolina Alumni Association with the Edward Kidder Graham Outstanding Faculty Award in 2005. Her contributions as an administrator in women's sports were recognized by the Massachusetts Association of Intercollegiate Athletics for Women Jeanne Rowlands Award for Outstanding Achievement in Women's Sports, and her personal athletics accomplishments landed her in the Kenosha (Wisconsin) Sports Hall of Fame. She is Co-chair of the Sports and Entertainment Law Section of the North Carolina State Bar, a member of the ABA's Forum on the Sports and Entertainment Industries, the Sports Lawyers Association, the Sport and Recreation Law Association, and the North American Society for Sport Management.

\section{REFERENCES}

Acosta, R.V. \& Carpenter, L.J. (2008). Women in intercollegiate sport: A longitudinal, national, study, thirty-one year update. Retrieved January 18, 2008, from http://webpages.charter.net/womeninsport/2008\%20Summary\% 20Final.pdf

Anderson, P. (2006). Review essay: A place on the team: the triumph and tragedy of Title IX. Marquette Sports Law Review, 16, 461-467.

Athletics, 34 C.F.R. Part 106.41 (2007).

Barnes v. Gorman, 536 U.S. 181 (2002).

Bennett v. West Texas State University, 799 F.2d 155 (5th Cir. 1986).

Bibby v. Philadelphia Coca Cola Bottling Co., 85 F.Supp. 2d 509 (E.D. Pa. 2000).

Blalock v. Dale County Board of Education, 84 F. Supp. 2d 1291 (D. Ala. 1999).

Bonnette, V. \& Daniel, L. (1991). Title IX investigators manual. United States Department of Education, Office for Civil Rights: Washington, D.C.

Cannon v. University of Chicago, 406 F.Supp. 1257 (N.D. Ill. 1976), affirmed, 559 F.2d 1063 (7th Cir. 1976), reversed, 99 S.Ct. 1946 (1979)

Cape v. Tennessee Secondary School Athletic Association, 424 F. Supp. 732 (E.D. Tenn. 1976).

Civil Rights Restoration Act, 20 U.S.C. $§ 1687$ (2007).

Cobb v. U.S. Dep't of Educ., Civil File No. 05-2439 (MJD/ALB), 2006 U.S. Dist. LEXIS 39985 (D. Minn. 2006), motion granted, motion denied, claim dismissed, 487 F.Supp.2d 1049 (D. Minn. 2007).

Cohen v. Brown University, 101 F.3d 155 (1st Cir. 1996). 
Cohen v. Brown University, 809 F. Supp. 978 (D. R.I. 1992), affirmed \& remanded, 991 F.2d 888 (1st Cir. 1993).

College Sports Council v. Department of Education, 465 F.3d 20 (D.C. Cir. 2006).

Communities for Equity v. Michigan High School Athletic Association, 26 F. Supp. 2d 1001 (W.D. Mich. 1998), reaffirmed on remand, 459 F.3d 676 (6th Cir. 2006).

Cook v. Colgate University, 802 F. Supp. 737 (N.D.N.Y. 1992), vacated, remanded, 992 F.2d 17 (2d Cir. 1993).

Davis v. Monroe County Board of Education, 526 U.S. 629 (1999).

de Varona, D. \& Foudy, J. (2003, February). Minority Views on the Report of the commission on Opportunity in Athletics. Retrieved January 15, 2008, from http://www.womenssportsfoundation.org/binary-data/WSF_ARTICLE/pdf_ file/944.pdf

Dodson v. Arkansas Activities Association, 468 F. Supp. 394 (E.D. Ark. 1979)

Doe v. Dallas Independent School District, 153 F.3d 211 (5th Cir. 1998).

Education Amendments of 1974, P.L. 93-380, 88 Stat. 612 (1974).

EEOC v. Madison Community Unit School District, 43 Fair Empl. Prac. Cas. (BNA) 1410 (1987).

Equity in Athletics, Inc. v. Department of Education, 504 F. Supp. 2 d 88 (D.C. Virg. 2007).

Favia v. Indiana University of Pennsylvania, 812 F. Supp 578, 584 (W.D. Pa. 1992).

Franklin v. Gwinnett County Public Schools, 503 U.S. 60 (1992).

Gebser v. Lago Vista Independent School District, 524 U.S. 274 (1998).

Gomes v. Rhode Island Interscholastic League, 469 F. Supp. 659 (D.R.I. 1979), vacated, 604 F.2d 733 (1st Cir. 1979).

Gonyo v. Drake University, 837 F. Supp. 989 (S.D. Iowa 1993).

Grove City College v. Bell, 465 U.S. 555 (1984).

Harris v. Portland, Civ. No. 05-2648, 6 (M.D. Pa. 2005).

H.M. v. Jefferson County Board of Education, 719 So.2d 793 (Ala. 1998).

Horner v. Kentucky High School Athletic Association, 43 F.3d 265 (6th Cir. 1994).

Jackson v. Birmingham Board of Education, 544 U.S. 167 (2005). 
Jennings v. University of North Carolina, 340 F. Supp. 2d 666 (M.D.N.C. 2004), affirmed, 444 F.3d 255 (4th Cir. N.C. 2006), rehearing en banc granted, No. 04-2447, CA-99-400-1, 2006 U.S. App. LEXIS 32390 (4th Cir. 2006), different results reached on rehearing, remanded by, 482 F.3d 686 (4th Cir. 2007).

Jones v. Oklahoma Secondary School Activities Association, 453 F. Supp. 150 (W.D. Okla. 1977).

Kelley v. Board of Trustees, 832 F. Supp. 237 (C.D. Ill. 1993).

Landow v. School Board of Brevard County, 132 F. Supp. 2d 958 (D. Fla. 2000).

Lantz v. Ambach, 620 F. Supp. 663 (S.D.N.Y. 1985).

Leffel v. Wisconsin Interscholastic Athletic Association, 444 F. Supp. 1117 (E.D. Wis. 1978).

LexisNexis Total Research System (n.d.). Available: www.lexis.com

Lichten v. State University, 646 N.Y.S.2d 402 (N.Y. App. Div. 1996).

Mason v. Minn. State High Sch. League, 2003 U.S. Dist. LEXIS 23460 (D. Minn. 2003).

Mercer v. Duke Univiversity, 50 Fed. Appx. 643 (4th Cir. 2002), affirmed, 401 F.3d 199 (4th Cir. 2004).

Miami University Wrestling Club v. Miami University, 302 F.3d 608 (6th Cir. 2002).

National Wrestling Coaches Association v. United States Department of Education, 263 F. Supp. 2d 82 (D.D.C. 2003), rehearing denied by, 383 F.3d 1047 (D.C. Cir. 2004).

NCAA v. Califano, 444 F. Supp. 425 (D. Kan. 1978).

NCAA v. Smith, 525 U.S. 459 (1999).

Neal v. Board of Tr., 198 F.3d 763 (9th Cir. 1999).

North Haven Board of Education v. Bell, 456 U.S. 512 (1982).

O'Connor v. Board of Education of School District 23, 449 U.S. 1301 (1980)

O'Connor v. Peru St. College, 605 F.Supp. 753 (D. Neb. 1985), affirmed, 781 F.2d 632 (8th Cir. 1986).

Osborne, B. (2003). Title IX in the $21^{\text {st }}$ century. Marquette Sports Law Review, $14,141-162$.

Ray v. Antioch Unified Sch. Dist., 107 F. Supp. 2d 1165 (N.D. Cal. 2000). 
Revised sexual harassment guidance: Harassment of students by school employees, other students, or third parties, 66 Federal Register 5512 (January 19, 2001). Retrieved January 15, 2008, from http://www.ed.gov/legislation/ FedRegister/other/2001-1/011901b.html

Simpson v. Univ. of Colo., 500 F.3d 1170 (10th Cir. 2007).

Strong v. Demopolis City Board of Education, 515 F.Supp. 730 (S.D. Ala. 1981).

The Secretary of Education's Commission on Opportunity in Athletics (2003, February 28). "Open to All” Title IX at Thirty. Retrieved January 15, 2008, from http://www.ed.gov/about/bdscomm/list/athletics/report.html

Title IX of the Education Amendments of 1972, 20 U.S.C. §1681, et. seq. (2007).

Title IX of the Education Amendments of 1972; A Policy Interpretation; Title IX and Intercollegiate Athletics, 44 Fed. Reg. at 71,423 (December 11, 1979). Retrieved January 15, 2008, from http://www.ed.gov/about/offices/ list/ocr/docs/t9interp.html

United States Department of Education, Office for Civil Rights (2005, March 15). Additional clarification of intercollegiate athletics policy: Three-Part test - Part three (March 17, 2005). Retrieved January 15, 2008, from http://www.ed.gov/about/offices/list/ocr/docs/title9guidanceadditional.html

United States Department of Education, Office for Civil Rights (2003, July 11). Further Clarification of Intercollegiate Athletics Policy Guidance Regarding Title IX Compliance (July 11, 2003). Retrieved January 15, 2008, from http://www.ed.gov/about/offices/list/ocr/title9guidanceFinal.html

United States Department of Education, Office for Civil Rights (1997). Sexual Harassment Guidance: Harassment of Students by School Employees, Other Students, or Third Parties. 4000-01-P. Retrieved January 15, 2008, from http://www.ed.gov/about/offices/list/ocr/docs/sexhar00.html

United States Department of Education, Office for Civil Rights (1996, January 16). Clarification of Intercollegiate Athletics Policy Guidance: The ThreePart Test Retrieved January 15, 2008, from http://www.ed.gov/about/offices/list/ocr/docs/clarific.html

United States Department of Education, Office of Postsecondary Education (n.d.). Equity in athletics data analysis cutting tool website. Available: http://ope.ed.gov/athletics/

United States Government Accounting Office (2001, March). Intercollegiate athletics: Four-year colleges' experiences adding and discontinuing teams. No. 01-297. Retrieved January 15, 2008, from http://www.gao.gov/ new.items/d01297.pdf 
United States Government Accounting Office (2007, July). Intercollegiate athletics: Recent trends in teams and participants in National Collegiate Athletic Association sports. GAO-07-535. Retrieved January 24, 2008, from http://www.gao.gov/new.items/d07535.pdf.

U.S. Census Bureau (n.d.) Cumulative Estimates of Population change for the United States, States, \& Puerto Rico - April 1, 2000 - July 1, 2007. Retrieved January 24, 2008, from http://www.census.gov/popest/gallery/ maps/maps-state2007.xls

Westlaw (n.d.). Available: www.westlaw.com

Williams v. Board of Regents of the University System of Georgia, 477 F.3d 1282 (11th Cir. 2007).

Wills v. Brown Univ., 184 F.3d 20 (1st Cir. 1999).

Woelber, E. (2006, November 10). Yale and Title IX: Female athletes get a fair shot. The Yale Herald. Retrieved January 15, 2008, from http://www.yaleherald.com/article.php?Article=5052 